\title{
The symbolism of Mesopotamian cult images
}

\author{
By!HELMER RINGGREN
}

Is. $44: 12-20$ contains a satirical description of the way the pagans, i.e., the Babylonians, make their "gods", i.e., their idols. "The ironsmith fashions it and works it over the coals; he shapes it with hammers, and forges it with his strong arm ... The carpenter stretches a line, he marks it out with a pencil; he fashions it with planes, and marks it with a compass; he shapes it into the figure of a man, with the beauty of a man, to dwell in a house. He cuts down cedars", he plants holm trees and oaks and lets them grow. Some he uses for fuel to warm himself or to bake bread, of others "he makes a god and worships it". With these and similar words the prophet ridicules those who make cult images.

This might of course be an independent literary creation-and perhaps it is-but interestingly enough there is a Babylonian text that could well have served as the prophet's model. In a ritual for the akitu festival in Babylon from Seleucid times we read about the third day as follows: "When it is three hours after sunrise, he shall call a metalworker and give him precious stones and gold from the treasury of the god Marduk to make two images for (the ceremonies of) the sixth day. He shall call a woodworker and give him (some) cedar and tamarisk (pieces). He shall call a goldsmith and give him (some) gold."

Then the work shall be distributed: the tail (?) to the metalworker, the breast to the goldsmith, the thigh to the woodworker, the ribs to the weaver. A detailed description of the images follows: 7 fingers high, one of cedar, one of tamarisk, precious stones shall be mounted, one image shall hold in its left hand a snake (made) of cedar, the second a scorpion. They shall be clothed in red garments, and they shall be placed in the house of the god Madan until the sixth day. Then their heads shall be stricken off and they shall be thrown into a fire that has been kindled ${ }^{1}$.

It is obvious that the images in question are not cult images in a real sense, i.e., images to be set up in a temple to receive sacrifices and worship, but images intended to be used in a "magical" ceremony: they represent evil forces that shall be annihilated by means of destroying their images in fire. At the same time, the text shows that it was well known how these images were made, but also that this did not detract from their symbolic, or magical, value.

${ }^{1}$ Cf. ANET $331 \mathrm{f}$. 
Unfortunately, we are not told how the Babylonians conceived of the relationship between the images and the evil beings which they symbolized. We have to draw our conclusions from what we can, so to speak, read between the lines.

Let us first consider the linguistic usage! "Image" in Accadian is salmu, and there are examples of both șalam ilani, "image of god(s)" and e.g. șalam huräși, "golden image"'. Salmu also means "royal image, royal statue", and it is not without interest that kings often set up their images in conquered cities in order to mark their presence and to show that they were ruling there.

In addition, however, the very word ilu, "god", can be used with reference to the image or statue of the god. There are such expressions as "to anoint the gods", to carry away gods and men as booty, to remove the gods from their pedestals, to send back (the queen of Arabia and) the gods to their country, to restore or to renew the gods, and so on. It can be said that "the high priest carries (the image of) Marduk, and the king walks before the god (i.e. his image)"' . All this suggests that the image in some way was the god, or that the god let himself be represented by the image.

Other texts bear witness to the same kind of "identity". We are told that a god may become angry because his temple has been neglected and then leave it. Esarhaddon says that Marduk was angry and allowed Babylon to be destroyed, and then "the gods who dwelt therein flew away like birds and went up to heaven"4. Other texts give reason to suspect that in reality it was enemies that carried away the images and so put an end to the gods' presence.

A Sumerian text called "The Curse of Agade" contains the following passage: "She has gone from the city, left it; like a maid who forsakes her chamber, the holy Inanna has forsaken her Agade shrine; like a warrior with raised weapons she attacked the city in fierce battle." It is not entirely clear if this is a circumlocution for the attack of enemies and their carrying away the image of the goddess, but much suggests that this is the case. It is probable at least that the whole poem deals with the fall of the city as a consequence of the attack of the Gutians.

In any case, "the role of the image was central in the cult as well as in private life", been found. "The deity was considered present in its image if it showed certain specific features and paraphernalia and was cared for in the appropriate manner" established by tradition ${ }^{7}$.

Most images were made of precious wood and were either covered with garments or plated with gold. The eyes were made of precious stones. "The

${ }^{2} \mathrm{AHw} 3,1078 \mathrm{f}$.

${ }^{3}$ CAD 7, $102 \mathrm{f}$.

${ }^{4}$ Quoted in CAD 7, 97.

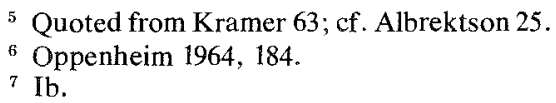


garments were changed in special ceremonies according to ritual requirements." Generally the images had human shape ${ }^{8}$.

Oppenheim says that "the king and the god Assur [were] often represented in identical attire and pose", which suggests that "the image of the national god could reflect that of his priest, the king"'. In support of this he refers to an inscription on the bronze reliefs mounted on the gate of the New Year's Chapel in Assur, "the figure of Assur going to battle against Tiamat is that of Sennacherib". But this could also mean that the king played the role of Assur in his battle against Tiamat in the ritual drama of the New Year's Festival.

The image had two main functions: it "served as the focal point for sacrificial activities", and it was carried in the processions of the great cultic festivals ${ }^{10}$. The image stood on its pedestal in the cella and functioned as a king in his palace. The temple was his "house" $(\mathbb{E}=$ bitu $)$. In general the public was not allowed to enter the cella, but the image was visible from the courtyard through a row of doorways. But it could be seen by the public when it was carried in procession ${ }^{11}$.

The sacrifices were regarded as meals and were served in the same way as the meals of the king. Food was placed in front of the image, music was performed, and incense was burned. As Oppenheim observes, the god "was apparently thought to consume [the food] by merely looking at it" 12 . It could also be passed in a swinging motion before the eyes of the image. After the food had thus been presented to the image, it was taken away and sent to the king for counsumption ${ }^{13}$. This privilege of the king is illustrated by Sargon II's remark: "The citizens of Babylon and Borsippa, the temple personnel, the scholars, and the administrators of the country, who formerly looked upon [Merodach-Baladan] as their king, now brought the leftovers of Bel and Sarpanitu, Nabu and Tasmetu to me at Dur-Ladinni and asked me to enter Babylon." 14 In other words, Sargon was offered the privilege that normally belonged to the king of Babylon. It is possible that the high officials of the sanctuary enjoyed the same privilege in some cases.

Jacobsen thinks that there was identity not only between the god and his image but also between the god and his temple. He speaks of "closeness of essence with the power inhabiting it (the temple)", or, in some cases, "making the temple more nearly an embodiment than a habitation"15. The argument seems strained; it is built mainly on the fact that temples sometimes have names resembling divine epithets, e.g. E-kur, "housemountain", cf. Enlil's epithet Kur-gal, "great mountain", E-babbar, "house-rising sun".

\footnotetext{
${ }^{8}$ Cf. Ib. 189.

9 Ib. 185 .

$10 \mathrm{Cf}$. Ib.

11 Cf. Ib. $186 \mathrm{f}$.
}

12 Ib. 192.

13 Cf. Ib. 189.

$14 \mathrm{Ib}$.

15 Jacobsen 16. 
We now revert to the making of images. In order to make an image suitable as a symbol of a god it must be consecrated. This was done by means of a ritual that was called pet $p \bar{l}$, "opening of the mouth". At least two versions of the ritual are preserved, the most complete one was published by Sidney Smith ${ }^{16}$ and later by Ebeling ${ }^{17}$. The procedure was the following.

Two pots of holy (pure) water were set up in the workshop, a red cloth was placed in front of "the god" (i.e. the image) and a white cloth beside him (red is the colour of death, white of life), and a preliminary "washing of the mounth" (mes pi) was performed on the newly made image. The officiating priest recited incantations, as e.g. "You who are born in heaven", and "From this time forth you shall go before your father Ea". In the night the image was carried in the light of torches to the bank of the river and placed on a reed-mat (symbol of the mother goddess, i.e. of birth) facing east. Sacrifices and libations were performed, incantations recited and the washing of the mouth repeated. The god was turned towards the west, and new sacrifices, incantations and mouth-washing were performed. Each incantation was obviously intended to make a certain part of the statue "perfect". A ram was sacrificed, then followed the incantation "Holy image that is perfected by a great ritual". The priest "opened the god's eyes" by touching them with a twig of tamarisk. Then the god was taken by the hand and led to his temple, accompanied by the incantations "Foot that advances", and "When he goes in the street". At the gate, sacrifices were performed, the god was taken into the temple and seated on his throne. Another washing of the mouth took place, whereupon the god received his divine insignia.

Everything goes to show that the ceremony was the symbol of a birth, the image was given "life". This is further illustrated by a text quoted by Ebeling, "This god of the New Moon ... the work of human beings ... without opening of the mouth he does not smell the incense, does not eat herbs, does not drink water." ${ }^{18}$ Ebeling concludes: "Also bewirkt die Mundöffnung, der die Mundwaschung mit heiligem Weihwasser vorangeht, die Belebung der Gottesstatue, die vorher nichts als Materie ( $t i t u)$ ohne Leben (napistu) oder Geist (saru) des Gottes gewesen ist."19

The last lines of the ritual suggest that it was the insignia and not the shape of the image that were essential. Oppenheim has also shown that the garments of the divine image, in many cases at least, represented the sky, the adornments being the stars, etc. ${ }^{20}$. As is well known, most of the gods were celestial gods.

The aim of the ritual was obviously to make the image a true and living representative of the god and to enable him to partake of the sacrificial

${ }^{16}$ Cf. Smith $37 \mathrm{ff}$.
${ }^{17}$ Cf. Ebeling $100 \mathrm{ff}$., see also Oppenheim
$1964,186$.
${ }^{18}$ Ebeling 100.

${ }^{19} \mathrm{Ib}$.

${ }^{20}$ Cf. Oppenheim 1949, $172 \mathrm{ff}$. 
meals presented to him. Unfortunately, the ancient Babylonians have not told us how they conceived of the relationship between the image and the god in heaven. It is obvious, though, that through his image the god was thought to be present in his temple.

\section{Bibliography}

AHw Soden, W. von, Akkadisches Handwörterbuch

ANET Ancient Near Eastern Texts related to the Old Testament. Ed. by J. Pritchard

CAD Chicago Assyrian Dictionary

JNES Journal of Near Eastern Studies

JRAS Journal of the Royal A siatic Society

Albrektson, B., 1967, History and the gods (Coniectanea Biblica, O.T. series 1). Lund.

Ebeling, E., 1931, Tod und Leben nach den Vorstellungen der Babylonier 1. Berlin.

Jacobsen, T., 1976, The treasures of darkness. New Haven.

Kramer, S., 1963, The Sumerians. Chicago.

Oppenheim, A., 1949, The golden garments of the gods. JNES 8.

- 1964, Ancient Mesopotamia. Chicago.

Smith, S., 1925, The Babylonian ritual for the consecration and induction of a divine statue. JRAS 